\title{
The Development of the Public-Private Partnership Concept in Economic Theory
}

\author{
Alla Mostepaniuk \\ Department of Economics, Girne American University, Kyrenia, TRNC \\ Email: allamostepaniuk@gau.edu.tr
}

How to cite this paper: Mostepaniuk, A. (2016). The Development of the PublicPrivate Partnership Concept in Economic Theory. Advances in Applied Sociology, 6, 375-388.

http://dx.doi.org/10.4236/aasoci.2016.611028

Received: October 17, 2016

Accepted: November 21, 2016

Published: November 24, 2016

Copyright $\odot 2016$ by author and Scientific Research Publishing Inc. This work is licensed under the Creative Commons Attribution International License (CC BY 4.0). http://creativecommons.org/licenses/by/4.0/

\begin{abstract}
The paper is aimed at the historical research of the approaches to identify the concept of public-private partnership and support its necessity in various conditions and countries by representatives of different scientific economic schools. Using methods of analyzing and interpreting of historical conditions and evidences as well as original scientific papers, the key stages of public-private partnership concept historical development were discovered and described.
\end{abstract}

\section{Keywords}

Public-Private Partnership, State, Business, Private Sector, Public Sector

\section{Introduction}

The present understanding of public-private partnership (PPP) is largely based on long and complicated process of development of the concept of cooperation between private and state sectors in economic theory. The practice of PPP projects implementation in transitional and market economies provides the contradiction information that is caused by inappropriate methods of implementation, imperfect legal regulation and other features of each particular country. That is why it is important to analyze the historical development of the concept, features, characteristics of cooperation between the state and business within the time frame from XVI century till the beginning of XXI in order to understand the key purpose of PPP, mechanisms of its implementation, the distribution of costs and benefits between partners and to identify sectors of economy, where PPP projects can be efficient for society as a whole.

\section{Methodology of Research}

To achieve the goal of the paper, methods of structure-function analysis were used to 
identify the impact of historical changes in the society on the understanding the efficiency and necessity of public-private cooperation for different stages of economic development; comparative analysis was conducted to show the differences in governmental policies for and against the cooperation between the state and business sectors based on current economic issues and key goals for further economic development, historical analysis was done to investigate the evolution of scientific approaches of public-private partnership in various countries through different time frames.

\section{Results of Research}

Relations between the state and the private sector attracted the attention of scientists throughout the period of economic development. Representatives of different schools of economic thought interpreted differently the necessity and nature of cooperation between these agents.

\subsection{Mercantilism}

Analysis of the evolution of scientific approaches regarding the identifying the meaning of interactions between state and business shows that the first who argued for cooperation between the state and private capital were mercantilists (XVI-XVII centuries). During that period, in Western countries trade capital needed the strong government to eliminate obsolete restrictions and to secure the international trade. On the other hand, the state was interested in the development of trade in order to meet the growing need for money to finance their expenditures.

It is known, that a key feature of the economic policy of mercantilism was protectionism, aimed at supporting the expansion of commercial capital, protection and promotion of the national industries; increasing domestic production of goods for export; restricting the import of finished products; baring or limiting the export of raw materials and encouraging its import to support low export prices for finished products. Thus, the state interacted with the private sector through the implementation of mandatory control for all trading operations by charging for each transaction fee.

The leading idea of mercantilism was the comprehensive cooperation between the state and national manufacturers to provide positive money balance (early mercantilists) or trade balance (later mercantilists). The most remarkable representatives of mercantilism such as Thomas Mann, Antoine de Montchrestien et al. in their papers grounded the essential need of governmental stimulation of cheap raw materials import in order to protect domestic producers from foreign competition and support exporters of national production. The key method to achieve these objectives was to conduct a trade protectionist policy (Bazylevych, 2004).

\subsection{Classical Political Economy.}

The founder of classical political economy in Britain, William Petty, considered the cooperation of state and private capital as a mechanism to regulate foreign trade, to build up trade and to expand the colonies of England, to implement protectionist policies 
aimed at supporting the domestic market. In the paper "Treatise of Taxes and Contributions" (1662) he explained the necessity to replace import duties with costs of public insurance, emphasizing and that this method of cooperation between the state and private business would contribute to achieving common benefits when a merchant's own interests will make him more willing to obey and pay (Petty, 1662).

The establishment of classical political economy in France was held during the socioeconomic crisis. As tough exploitation of peasants, artificially keeping low prices for agricultural products, free entry into the country of grain and raw materials, forbidden their export caused the economic decline. During this period the protectionist policy on cooperation of state and business was suggested by the Minister of Finances, France Jean-Baptiste Colbert, and the policy was aimed at achieving active trade balance and strengthening the government power (Bazylevych, 2004).

\subsection{Physiocracy}

The school of Physiocracy that emerged in the late XVIII century in France denied the basic doctrines of mercantilism on cooperation between the state and the private sector, arguing that the most important source of enrichment of the state is agriculture. At the core of the proposed concept of cooperation between state and private capital, objective conditions of free competition era are laid, which included the support functions of the state in economic system based on private property and freedom of entrepreneurship. It is a fundamental principle of economic liberalism, which is to promote the comprehensive application of competition and state regulation only where it cannot be done without. Thus, the founder of Physiocracy theory François Quesnay considered the basis of the "natural order" are economic freedom, inviolability of private interests and property rights. Following the principles of economic liberalism, the scientist claimed "the need for free trade as a prerequisite for the enrichment of merchants that will increase the government revenue" (Quesnay, 1756).

According to François Quesnay, the "natural order" is implemented in real life because of "positive laws" - "outgoing rules established by the sovereign authority to secure the public order, to protect society and the constant obedience of natural laws" (Quesnay, 1756).

Thus, unlike the natural, positive laws are the result of government actions that leads to volatility and imperfections. Therefore, an important task of Physiocracy is to study the natural economic laws in order to implement the adequate normative regulation system.

Representatives of classical political economy made a significant impact on the evolution of concept on economic cooperation between the state and business, based on the fact that unlimited affect by the natural economic laws has a positive impact on society, which needs free competition supporting and providing free of state regulation entrepreneurship. According to the classical theory, to provide the "honest partnership" is an important economic function of the state and necessary for efficient operation of the market mechanism. All market agents reach different results, guided by their own 
interests through the use of limited resources. Their individual work is a natural source of a private property, the protection of which relies on the state. Here, the property is defined as public that bears certain rights, regulation and control, which relied on the state as the guarantor of accepted norms and traditions of private capital functioning (Smith, 1776).

\subsection{Classical Economic Liberalism}

It is important to note that representatives of classical economic liberalism paid considerable attention to the social component of cooperation between the state and private sector. The founder of the classical school of political economy Adam Smith assigned to state the role of a guarantee of freedom of action and private initiative for those independent individual agents that create social wealth. Supporting the "natural harmony" (a kind of equilibrium that is established spontaneously in a market economy in the absence of any outside intervention) A. Smith demanded the abolition of state regulation of industry and trade based on the assumption that "any policy intervention creates a significant disparity in the total gains and losses resulting from restrictions in competition". According to scientists, the government should be exempt from functions that cause constant contradictions, when to have knowledge is not enough to deal effectively with them (Smith, 1776).

In this context we can admit that from the ideas of economic liberalism of Adam Smith originated the concept of power division between the state and private capital, the state and society. Adam Smith acknowledged the need for the state intervention in the economy in certain sectors or activities where the individuals cannot return their invested funds; thereby the state should ensure the functioning of public enterprises. The representatives of the classical school of political economy recognized the need for the presence of the state where the production of goods and services doesn't make a quick return as infrastructure facilities. Thus, Adam Smith in his work "The Wealth of Nations" (1776) determined the industries that can be transferred to private business, accordingly joint stock companies can operate successfully only in areas where all operations can be reduced to routine which allows little or does not allow any changes. This kind of business includes: banks, insurance businesses, construction and maintenance of navigable canals and water supply enterprises (Smith, 1776).

An important contribution to the research on the interaction between state and private capital was made by John Stuart Mill (1806-1873), who shifted the emphasis from the analysis of economic behaviour of the individual to the collective forms of business (joint-stock companies) and paid considerable attention to social issues. Like all members of the classical school, the scientist was a supporter of the concept of economic liberalism, believed that the individual has the necessary business and entrepreneurship skills that are missed by the state. He also drew attention to the source and spread of monopoly ownership, which caused the rise of negative effects by restricting free competition. Being against private monopolies John Stuart Mill supported the need of economic control in the form of state monopolies, particularly in infrastructure (Mill, 1848). 
John Stuart Mill in his work "Principles of Political Economy with some of their Applications to Social Philosophy" (1848) pointed out that the state may own the canals and railroads, not exploiting them because they are almost always better exploited by private companies that take property on lease for a period. The point is that the state should define the conditions for a private enterprise operation to provide a public benefit or maintain its power for the benefits received by society. The key idea was formulated and later transformed into a systematic concept of the public-private partnership (PPP). John Stuart Mill is the first who drew attention to the appropriateness of the concession-the form of PPP with the state's right to take back in certain circumstances the property that are important for the society or continue to control and adjust prices for services provided by the private business (Mill, 1848).

\subsection{German Historical School}

At the same time, a socio-economic stage of development in Germany at the beginning of XIX century (crises of national industry, the need for economic and political uniting of the country, the threat of turning it into a raw material supplier and market for finished products produced by more developed countries) prepared the foundation for the establishment of alternative to classical political economy approach of economic thought called the German historical school. The founder of this school Daniel Friedrich List believed that the economy cannot be understood as an organic entire, excluding from it the features of a nation state. In his landmark work "The National System of Political Economy" (1841) the scientist criticized the basic ideas of the classical school of economics. He denied the existence of universal economic laws based on the uniqueness of national economies and stressed the priority on studying unique features of a national economy, identifying the real national interests and specific laws of economic development of an individual country in order to determine the role and functions of the state in a partnership with a private capital and create favorable conditions for their economic potential implementation (List, 1841).

The concept of gradual economic development established by Daniel Friedrich List emphases that the form of interaction between the state and private capital should take into account the characteristics of each economic development stage of the nation in order to create the preconditions for its growth. According to the approach for countries that are in II (agriculture) and IV (agriculture, manufactures and commerce are combined) stages a policy of state interference in international trade is needed, which allows to realize fully the economic opportunities of the country. For countries that are in III (agriculture united with manufactures) stage there is a need for cooperation between the state and business aimed at protecting national industry (List, 1841).

Thus, according to the Historical school of economics, the state free trade policy is required only in circumstances where all countries achieved the same stage of development; otherwise, free trade will be beneficial only for the most developed countries, the less developed countries will be in an inferior position. Daniel Friedrich List was convinced that protectionism is justified only as a learning tool aimed at the development 
of the productive forces of nations and the alignment of economic development.

Particular attention was paid by the scientist to necessity of the public sector development as a vital part of the national economic system. He studied the impact of political unity and governance on economic development, the progress of national production and increase in the national wealth. According to the researcher, the cooperation of the state and the private sector should coordinate and guide the efforts of individual elements of the national economy in the direction of long-term interests of the nation (List, 1841).

Representatives of the Historical school of economics didn't limit the state activities as a "night watchman". According to their believes, in a market economy the state's role is to create physical, institutional and cultural preconditions for the rapid industrial rise of a country and the establishment of a mutual local market, harmonization of public interests and concentration of efforts to cope with the nation's strategic future challenges.

\subsection{Neoclassical Economics}

Over the last 30 years of XIX century classical economics was replaced by neoclassical economic theory. Representatives of the neoclassical economics (Alfred Marshall, John Bates Clark, Vilfredo Pareto etc.) followed the ideas of economic liberalism based on the fact that the development of a market economy is supported through its free competition and the laws of self-regulation. Thus, A. Marshall believed that economic freedom and competition are the key driving forces of society. However, A. Pigou, a representative of the Cambridge school of neoclassicism, in his papers proved the idea on a government's role in a market economy. According to A. Pigou, for any industry, for which there is a reason to believe that based on free business actions the amount of resources invested will be less than it is necessary in terms of a national welfare increase, there is a reason for government to intervene. He proved that the state's role is to internalize externalities, transform from implicit to explicit distinction between private and public interests. However, a prerequisite of achieving economic development is free competition, which ensures the realization of private interests and unrestricted movement of goods (Pigou, 1920).

An important contribution to the understanding of relations between the state and business in a market economy was made by John Bates Clark, the founder of American neoclassical economics, he criticized the classic economic theory as "the apotheosis of egoism" and argued for cooperation between the state and the private sector to ensure fair distribution of wealth, replacing conflicts and competition with mutually beneficial cooperation. In his work "The Distribution of Wealth: A Theory of Wages, Interest and Profits" (1899) he identified the property rights protection as the core function of the state, the property has to be protected wherever it occurs, as the current salary equals to the full product of labor, as an interest, which is the product of capital and profit as a product of the coordination process (Clark, 1899).

The research on partnership of the state and business in the Ukrainian economic 
literature in this period was reflected in the works of a famous scientist, a statesman, an ideologist of market reforms in XIX century Nikolai Bunge (1823-1895), who believed that the effective development of a market economy in Russia and Ukraine is possible only if it is supported by the state.

According to Nikolai Bunge, "freedom is a necessary condition for the development of economic life and to treat economic infirmities", the state's role is to ensure the legal protection of a private property and entrepreneurship, legal regulation of customs and monetary policy; to implement antitrust laws, to maintain the macroeconomic equilibrium between supply and demand (Bunge, 1870).

Therefore, special attention was devoted by the researcher on identifying the role of public institutions in socially important sectors, affecting the interests of the general population, such as the railway sector and banks. Stressing the importance of legal institutions' role in the economic system, he noted that "the widest freedom does not exclude legal norms, which are established not for restriction on business but for providing the opportunity for everyone to use those rights that belong to business" (Bunge, 1870).

The prominent Ukrainian economist Mikhail Ivanovich Tugan-Baranovsky (18651919) in his work "Foundations of Political Economy" (1909) explored the relationship between the state and business in a market economy based on the assumption that the state restricts the freedom of a firm's actions by guiding them in order to fulfil a specific plan that is announced by the state. The object of the state regulation and trade unions primarily is the division of welfare, which by its nature is a social rather than a market function (Tugan-Baranovsky, 1909).

Since the 30s of XX century the debate on the issues of state interference and freedom of economic activity, protectionism and free trade policy had started. New approaches of research on forms, methods and mechanism of cooperation between a state and a private sector initiated at that time didn't lose their value until now. Since that time two key theories are focusing on solving the problems of public-state cooperation that can be divided into two fields: Keynesianism and Neoliberalism.

\subsection{Keynesianism}

The key concept of John Maynard Keynes study is mentioned in his work "The General Theory of Employment, Interest and Money" (1936), in contrast to the classical economics John Maynard Keynes denied self-regulation of a market economy, arguing that there is no automatic mechanism that can ensure the stable development of the economy.

According to Keynesian economic theory, the market is unable to regulate the economy and provide full employment, stable production and prices. An active role should be played by the state, mostly by using a fiscal and monetary policy, which would moderate the sharp ups and downs of producing, which are defined as economic cycles. The effectiveness of the state regulation of economic processes depends on the availability of funds for public investment, the achievement of full employment, reducing and fixing the rate of interest (Keynes, 1936). 
The representatives of neo-Keynesian economic theory grounded the basic directions of state regulation of the economy towards establishing cooperation between the state and the business sector, particularly directing investments in productive and social infrastructure, development of public contracts (procurement) etc. in the 50-60s of XX century. The point is that having a large budget, the government should invest in the construction of roads, ports, airports, channels of communication, including computer networks, to ensure the appropriate conditions for manufacturing and the banking system. The construction of these facilities should be carried out, usually by private firms and financed by the state. However, the state should finance most of the fundamental (non-profitable) scientific researches and technological innovations that can bring financial return only in the long term; the role of the government is to finance venture (risk) companies (Keynes, 1936).

\subsection{Neoliberalism}

In contrast to the Keynesians, the supporters of economic neoliberalism denied the need for government intervention in the market economy. According to Friedrich Hayek, a spontaneous market order means that the state should not interfere in the economic system of society, because this could destabilize the market mechanism and paralyze the economic system as a whole. Moreover, any conscious control the economy, any economic policy aimed at getting certain results (policy aimed at reaching the full employment or economic growth, fighting against inflation or recession) is unachievable as it is not possible to take into account the variety of knowledge that is essential for the successful implementation of goals (Hayek, 1988).

Thus, the concept of a spontaneous market order by Friedrich Hayek basically denied any government interference in the economic system of society. According to Friedrich Hayek, the interaction of state and business in a market economy should be limited to institutional performance of state functions, which are to protect the natural social order-freedom of choice and development, free competition and monopoly. It is realized through the development of legislation, social moral values, protection of established traditions. The state should not be engaged in issues of social regulation, to provide social assistance, because it undermines the incentives for active economic activity. Individuals should receive only earned income, not to expect any help from the state. Social inequality, according to Friedrich Hayek, is a natural phenomenon that contributes to the development of society (Hayek, 1988).

Thus, the concept of neoliberalism is based on the principles of freedom of economic activity, free pricing, establishing the priority of private property and private business entities. However, modern neoliberals argue the legality of a limited state interference in economic processes and the general promotion of free and stable operation of the business as the most important preconditions for eliminating imbalances in the economy.

\subsection{Institutionalism}

In contrast to neoclassical ideas of economic liberalism and state non-interference in economic life, in the last third of the XIX century in the US alternative ideas were 
emerged in the form of traditional institutionalism, whose founders were ThorsteinBunde Veblen, John Rogers Commons and Wesley Clair Mitchell. This branch of opposition to economic theory was aimed at overcoming the defects of capitalism by its democratic reformation. Institutionalism denied the position of an "organized social action", they conducted the research of new forms of social organization and economic democracy, unlike these earlier ideas as a natural order and state non-interference in the economic system (Commons, 1934).

Institutionalists justified the necessity of state influence "defects" of the market mechanism associated with a sharp increase in social inequality, monopolization and crises, conflicts of private and public interests. The key for the representatives was the idea of creating a reliable mechanism of social control by society that would be able to ensure the stability of the economy and its controlled development. All supporters of institutionalism followed a common anti-monopoly orientation, studied the impact of social system on economic growth, and proved the necessary of cooperation between the state and private capital, especially in the form of "democratic public control over the business" (Commons, 1934).

\subsection{Neo-Institutionalism}

However, modern neo-institutionalism focuses on different forms of coordination in economic systems. Their focus was mostly on a market mechanism of self-regulation, government regulation mechanisms, as well as a very specific concept of rent seeking. The mentioned above method of coordination is fundamentally important for the understanding of the interaction between state and business within the transition to market economies.

The founder of this theory is an American the Nobel Prize-winning economist James McGill Buchanan, according to which, a person who is engaging in political activities, participating in the development and implementation of economic decisions, who serves as a public office (public servant, parliamentarian, and president) is not necessarily guided by the interests of public welfare. By using political (bureaucratic) institutions, a person tries to realize self-interests, gain political or economic "rents". Often the practice of lobbying (actions aimed at supporting public decisions in order to meet the interests of elites) and the theory of logrolling (mutual support of decisions by certain related groups in order to satisfy the interests of all members), trading votes (vote buying) are using. The main objective of rent seeking is to get some privileges, preferences, government loans, information or to limit competition. Representatives of this theory concluded that there is a political inequality and possibility of adopting irrational decisions for society. Therefore, they are not denying the role of the state, which should assure the development of free market under civilized legal basis (Buchanan \& Tullock, 1962).

The practice of public-private partnerships implementation in transition economies illustrates the theory of rent seeking when the authorities are interested in achieving mostly their own interests, using for that all the possibilities, as a result there is an 
imbalance between the state and society interests.

In the context of the study it is important to mention the theory of property rights, the main objective of the theory is to analyze the interaction between an economic and legal systems and it is based on the following assumptions: ownership determines what costs and rewards can be expected by agents for their actions; restructuration of property rights leads to changes in the system of economic incentives; responses to these changes may misled the behavior of economic agents (Bazylevych, 2004).

According to the theory of property rights, the implementation of public-private partnership practice leads to changes in the economic system of motives and causes fault changes in behavior of economic agents. The point is that the implementation of PPP projects provides a transfer of property rights from the state to the private partner, which in turn changes the expectations of economic agents and their behavior accordingly.

However, the theory of property rights based on the fact that at the result of a property right exchange the object will be transferred to a private partner that offered the highest price for it, and thereby the efficient allocation of resources in the economy will be achieved. This principle is also accurate in the process of choosing a private partner for PPP projects.

The theory of property rights determines the exclusion of certain economic agents from free access to the resource as the specification of ownership. Specification of ownership helps to create a stable economic environment, reduce uncertainty and stabilize expectations of individuals about what they can get as a result of their actions and what they can expect in relations with other economic agents. In addition, incomplete specification is defined as attenuation of property rights that can happen when they are not accurately set and poorly protected or because they are under different forms of state restrictions (Bazylevych, 2004).

The specification of ownership in transformation economies is caused by corruption when only certain economic agents have access to state property, although formally all private companies are eligible to bid for the implementation of PPP projects.

According to neo-institutionalists, the system of contracts (interactions) is defined as a principal-agent relationship, a method of interactions when one or more subjects (principals) draw (hire) another subject (agent) to perform actions (services), at the same time a principal delegates some decision making rights to an agent. The model of principal-agent interaction is based on assumptions that an agent selects one of the possible types of actions that influence his own welfare and the welfare of the principal. However, it is creating a situation when an agent maximizes not only its own benefit, but also the principal's (Dowrick, 1954).

This theory of relations clearly defines the relationship between the state and business in the implementation of PPP projects when the private partner provides public services or upgrades objects of public property on behalf of the state, at the same time receiving income and providing social services at the highest quality.

In the context of the study it is noteworthy to mention a work of a recipient of the 
Nobel Memorial Prize in Economic Sciences (2001) Joseph Stiglitz "Economics of the Public Sector" (2000), where the author studied features of providing public goods by the private sector. The author divided all public services into two groups; services that can be provided exclusively by the state and mixed that can be supplied efficiently by the state or by the private sector. According to Joseph Stiglitz, the private sector provision of social services is inefficient. If the product is provided by a private firm, it must fix a fee for its consumption; any payment will reduce the wiliness of people to use the product. Thus, when public goods are produced by the private sector, this leads to underutilization (Stiglitz, 2000).

However, providing public goods to satisfy the basic needs of society is the key feature of the public sector. At the same time, a large share of the public sector in the economy delays and restricts the development of other sectors of production, thereby destroys the market environment. Joseph Stiglitz stresses the differences that exist between private and public companies that have different goals; a private company's goal is to maximize its profit, for public companies the goal is to provide public services. There are differences in the systems of motivation in private and public sectors due to lack of competition and the probability of bankruptcy. The limited usage of a wage increase and job security as motivators may to some extent explain the differences in the behavior of individuals working in public and private enterprises (Stiglitz, 2000).

\section{Conclusions}

The development of cooperation between the state and the private sector was started in XVI century by economists that were trying to identify the efficient role of the state. The concept of the partnership between the state and business changed as new economic approaches and theories were established. The representatives of different economic schools had their own understanding of cooperation that can bring mutual benefits as for businesses, the state and society as a whole. The study allows us to specify the key approaches to understanding of cooperation between the state and business as following:

- The leading idea of mercantilism was the comprehensive cooperation between the state and national manufacturers to provide positive money balance (early mercantilists) or trade balance (later mercantilists). The essential need of governmental stimulation of cheap raw materials importing in order to protect domestic producers from foreign competition and support exporters of national products was proved.

- The founder of classical political economy in Britain, W. Petty considered the cooperation of state and private capital as a mechanism to regulate foreign trade, to build up trade and expand the colonies of England, to implement protectionist policies aimed at supporting the domestic market.

- The school of Physiocracy denied the basic doctrines of mercantilism on cooperation between the state and the private sector, arguing that the most important source of enrichment of the state is agriculture. At the core of the proposed concept 
of cooperation between state and private capital objective conditions of free competition era are laid, which included the support functions of the state in economic system based on private property and freedom of entrepreneurship. It is a fundamental principle of economic liberalism, which is to promote the comprehensive application of competition and state regulation only where it cannot be done without.

- According to the classical theory, to provide the "honest partnership" is an important economic function of the state and necessary for efficient operation of the market mechanism, all market agents reach different results, guided by their own interests through the use of limited resources.

- The historical school of economics argued that the state free trade policy is required only in circumstances where all countries achieved the same stage of development; otherwise, free trade will be beneficial only for the most developed countries, the less developed countries will be in an inferior position.

- Representatives of the neoclassical economics believed that economic freedom and competition are the key driving forces of society. According to the theory, for any industry, for which there is a reason to believe that based on free business actions the amount of resources invested will be less than it is necessary in terms of a national welfare increase, there is a reason for government intervention. They argued that the state's role is to internalize externalities, transform from implicit to explicit distinction between private and public interests. However, a prerequisite of achieving economic development is free competition, which ensures the realization of private interests and unrestricted movement of goods.

- According to Keynesian economic theory, the market is unable to regulate the economy and provide full employment, stable production and prices. An active role should be played by the state, mostly by using a fiscal and monetary policy, which would moderate the sharp ups and downs of producing, which are defined as economic cycles. The effectiveness of a state regulation of economic processes depends on the availability of funds for public investment, the achievement of full employment, reducing and fixing the rate of interest.

- The supporters of economic neoliberalism denied the need for government intervention in the market economy. According to F. Hayek, a spontaneous market order means that the state should not interfere in the economic system of society, because this could destabilize the market mechanism and paralyze the economic system as a whole. Moreover, any conscious control the economy, any economic policy aimed at getting certain results (policy aimed at reaching the full employment or economic growth, fighting against inflation or recession) is unachievable as it is not possible to take into account the variety of knowledge that is essential for the successful implementation of goals.

- Institutionalists justified the necessity of a state influence "defects" of the market mechanism associated with a sharp increase in social inequality, monopolization and crises, conflicts between private and public interests. The key for the represent- 
atives was the idea of creating a reliable mechanism of social control by society that would be able to ensure the stability of the economy and its controlled development.

- Modern neo-institutionalism focused on different forms of coordination in economic systems. Their focus was mostly on a market mechanism of self-regulation, government regulation mechanisms, as well as a very specific concept of rent seeking. The mentioned above method of coordination is fundamentally important for the understanding of the interaction between state and business within the transition to market economies.

- According to the theory of property rights the implementation of public-private partnership practice leads to changes in the economic system of motives and causes fault changes in behavior of economic agents. The point is that the implementation of PPP projects provides a transfer of property rights from the state to the private partner, which in turn changes the expectations of economic agents and their behavior accordingly. However, the theory of property rights based on the fact that at the result of a property right exchange the object will be transferred to a private partner that offered the highest price for it, and thereby the efficient allocation of resources in the economy will be achieved. This principle is also accurate in the process of choosing a private partner for PPP projects.

- Joseph Stiglitz studied features of providing public goods by the private sector, he divided all public services into two groups; services that can be provided exclusively by the state and mixed that can be supplied efficiently by the state or by the private sector. According to J. Stiglitz, the private sector provision of social services is inefficient. If the product is provided by a private firm, it must fix a fee for its consumption; any payment will reduce the wiliness of people to use the product. Thus, when public goods are produced by the private sector, this leads to underutilization.

Despite the changes in interpretation of partnerships that have occurred with the development of economic thought, the basic principles of effective cooperation between the state and business were grounded in the works of classical and modern economists and they are relevant even today. The key idea of efficient PPP projects is to attract private capital and their expertise to build and improve public infrastructure and to provide high quality public services.

\section{References}

Bazylevych, V. D. (2004). History of Economic Studies. Kyiv: Znannya.

Buchanan, J. M., \& Tullock, G. (1962). The Calculus of Consent: Logical Foundations of Constitutional Democracy. http://files.libertyfund.org/files/1063/Buchanan 0102-03 EBk v6.0.pdf https:/doi.org/10.3998/mpub.7687

Bunge, N. (1870). Basics of Political Economy. Kyiv: Kyiv University Press.

Clark, J. B. (1899). The Distribution of Wealth: A Theory of Wages, Interest and Profits. http://oll.libertyfund.org/titles/clark-the-distribution-of-wealth-a-theory-of-wages-interest-an d-profits

Commons, J. R. (1934). Institutional Economics. New York: Macmillan. 
Dowrick, F. E. (1954). The Relationship of Principal and Agent. The Modern Law Review, 17, 24-40. https:/doi.org/10.1111/j.1468-2230.1954.tb02143.x

Hayek, F. (1988). The Fatal Conceit: The Errors of Socialism. http://www.libertarianismo.org/livros/fahtfc.pdf

Keynes, J. M. (1936). The General Theory of Employment, Interest and Money. http://cas.umkc.edu/economics/people/facultypages/kregel/courses/econ645/winter2011/gener altheory.pdf

List, F. (1841). The National System of Political Economy. http://oll.libertyfund.org/titles/list-the-national-system-of-political-economy

Mill, J. S. (1848). Principles of Political Economy with Some of Their Applications to Social Philosophy.

http://oll.libertyfund.org/titles/mill-principles-of-political-economy-ashley-ed

Petty, W. (1662). A Treatise of Taxes \& Contributions. http://www.hargaden.com/enda/wp-content/petty taxescontributions.pdf

Pigou, A. (1920). The Economics of Welfare. http://files.libertyfund.org/files/1410/Pigou 0316.pdf

Quesnay, F. (1756). Economic Table. https://www.marxists.org/reference/subject/economics/quesnay/1759/tableau.htm

Smith, A. (1776) The Wealth of Nations. https://www.ibiblio.org/ml/libri/s/SmithA WealthNations p.pdf

Stiglitz, J. (2000). Economics of the Public Sector. New York/London: W. W. Norton.

Tugan-Baranovsky, M. I. (1909). Foundations of Political Economy. http://www.library.fa.ru/files/tugan baranovskiy.pdf

Submit or recommend next manuscript to SCIRP and we will provide best service for you:

Accepting pre-submission inquiries through Email, Facebook, LinkedIn, Twitter, etc. A wide selection of journals (inclusive of 9 subjects, more than 200 journals)

Providing 24-hour high-quality service

User-friendly online submission system

Fair and swift peer-review system

Efficient typesetting and proofreading procedure

Display of the result of downloads and visits, as well as the number of cited articles Maximum dissemination of your research work

Submit your manuscript at: http://papersubmission.scirp.org/

Or contact aasoci@scirp.org 